\title{
PERAN WORD OF MOUTH MEMEDIASI HUBUNGAN ANTARA IKLAN DAN HARGA TERHADAP MINAT BELI
}

\author{
Ida Ayu Ruby Kuberasyani' \\ Ketut Rahyuda ${ }^{2}$
}

${ }^{1,2}$ Fakultas Ekonomi dan Bisnis Universitas Udayana (Unud), Bali, Indonesia e-mail: rubykuberasyani13@gmail.com

\begin{abstract}
ABSTRAK
Penelitian ini bertujuan untuk mengetahui bagaimana word of mouth memediasi hubungan iklan dan harga dengan minat beli pada Traveloka.com dan mengetahui seberapa besar pengaruh iklan yang dilakukan Traveloka.com terhadap minat beli Traveloka.com. Penelitian ini dilakukan dengan penyebaran kuisioner pada 100 responden. Kriteria sampel dalam penelitian ini yaitu berdomisili di kota Denpasar, responden yang berpendidikan minimal SMA atau sederajat, responden belum pernah menggunakan traveloka.com. Jenis data yang di gunakan pada penelitian ini yaitu data kualitatif dan data kuantitatif. Teknik analisis data yang digunakan yaitu analisis statistic deskriptif, uji asumsi klasik, statistik inferensila, uji sobel, dan uji VAF. Berdasarkan hasil analisis, ditemukan iklan berpengaruh positif word of mouth, iklan berpengaruh positif terhadap minat beli, harga berpengaruh positif terhadap word of mouth, harga berpengaruh positif terhadap minat beli, word of mouth berpengaruh positif terhadap minat beli dan word of mouth mampu memediasi hubungan antara iklan dan harga terhadap minat beli.
\end{abstract}

Kata kunci: word of mouth, iklan, harga, minat beli

\begin{abstract}
This study aims to find out how word of mouth mediates the relationship of advertising and prices with buying interest in Traveloka.com and knows how much influence Traveloka.com advertisements have on the interest in buying Traveloka.com. This research was conducted by distributing questionnaires to 100 respondents. The sample criteria in this study are domiciled in the city of Denpasar, respondents who have at least high school or equivalent education, respondents have never used traveloka.com. The types of data used in this study are qualitative data and quantitative data. The data analysis technique used is descriptive statistical analysis, classic assumption test, inferential statistics, sobel test, and VAF test. Based on the results of the analysis, it was found that advertising had a positive effect on word of mouth, advertising had a positive effect on buying interest, prices had a positive effect on word of mouth, prices had a positive effect on buying interest, word of mouth had a positive effect on buying interest and word of mouth was able to mediate the relationship between advertising and prices for buying interest.

Keywords: word of mouth, advertising, price, buying interest
\end{abstract}




\section{PENDAHULUAN}

Pertumbuhan ekonomi di Indonesia melalui bisnis e-commerce sudah tidak diragukan lagi. Berdasarkan data dari e-Marketer menyebutkan jumlah pengguna internet di Indonesia setiap tahunnya terus bertambah. Pada tahun 2013 tercatat jumlah pengguna internet 72,8 juta , kemudian naik menjadi 102,8 pada tahun 2016 di 2017 pengguna internet di Indonesia mencapai 112,6 juta. Dengan pertumbuhan pengguna internet, Bank Indonesia memperkirakan ada 24,7 juta orang yang berbelanja online. Nilai transaksi e-Commerce diprediksi mencapai Rp 144 triliun pada 2018, naik dari Rp 69,8 triliun di 2016 dan Rp 25 triliun di 2014. (www.tekno.liputan6.com)

Travelling, saat ini sudah menjadi kebutuhan masyarakat pada umumnya. Mengunjungi destinasi baru disebuah daerah tertentu hanya untuk sekedar berwisata ataupun melakukan bisnis di daerah lain menjadi suatu alasan untuk berwisata. Kebutuhan hidup orang Indonesia travelling alias jalan-jalan merupakan salah satu alasan mereka untuk menabung (Gustiawati,2013).

Berbelanja secara online beberapa tahun terakhir menjadi cara baru yang dibuat oleh pemasar untuk memudahkan konsumennya. Kemudahan pembelian menjadi keunggulan dalam melakukan pembelian secara online, sukses menarik minat konsumen modern untuk berbelanja secara online, karena pembelian tersebut bisa dilakukan dimana saja dan kapan saja selama masih ada koneksi internet dan praktis dalam penggunanya (Saragih dan Rizky,2012).

Saat ini di Indonesia berbelanja secara online telah mengalami pertumbuhan yang pesat. Sekitar setengah konsumen Indonesia berencana untuk 
membeli secara online tiket pesawat(55\%) serta melakukan pemesanan hotel dan biro perjalanan (46\%) untuk enam bulan ke depan. Empat dari sepuluh konsumen $(40 \%)$ berencana untuk membeli buku elektronik (e-book), hampir enam dari sepuluh konsumen berencana untuk membeli pakaian/aksesoris/sepatu (37\%), dan lebih sepertiga konsumen merencanakan untuk membeli tiket acara (37\%) secara online (Lubis,2017).

Tabel 1.

Presentase Pembelian Online

\begin{tabular}{ccc}
\hline No. & Jenis Pembelian & $\mathbf{( \% )}$ \\
\hline 1. & Tiket pesawat & 55 \\
2. & Reservasi Hotel/biro perjalanan & 46 \\
3. & Buku elektronik/E-book & 40 \\
4. & Pakaian/aksesoris/sepatu & \\
5. & Pertunjukan/tiket acara & 34 \\
\hline
\end{tabular}
Sumber : Lubis, 2017

Salah satu perusahaan e-commerce di Indonesia yang sudah terbilang sukses dan kuat yaitu Traveloka.com dengan situs pemesanan tiket pesawat dan hotel untuk memenuhi kebutuhan masyarakat untuk informasi harga tiket dan fasilitas untuk pembelian secara online dari berbagai macam maskapai dimana konsumen tidak perlu mengecek satu-satu maskapai penerbangan lewat agen perjalanan atau membuka satu-satu situs dari tiap maskapai penerbangan (Sastika 2016:2).Traveloka.com adalah salah satu dari sekian banyaknya $e$ commerce yang sedang memiliki pertumbuhan yang cukup signifikan.

Menurut website Strartupranking.com, terdapat beberapa perusahaan startup yang dinyatakan stratup terbaik untuk kategori e-commerce, dapat dilihat Tabel 2 : 
Tabel 2.

Best Indoneisa Startup (E-commerce Category)

\begin{tabular}{ccc}
\hline Startup & Country Rank & Global Rank \\
\hline Tokopedia & 1 & 28 \\
Bukalapak & 2 & 54 \\
Blibli & 3 & 74 \\
Traveloka & 4 & 93 \\
Elevenia & 5 & 132 \\
Blanja.com & 6 & 165 \\
Zalora Indonesia & 7 & 175 \\
Tiket & 8 & 185 \\
Boalob & 9 & 207 \\
pulsk & 10 & 345 \\
\hline
\end{tabular}

Sumber: Startupranking.com, 2017

Berdasarkan Tabel 2 yang menjadi perusahaan startup terbaik untuk kategori Online Travel adalah Traveloka. Dari 10 Besar perusahaan startup, 7 di antaranya merupakan perusahaan Online shop, 2 Online Travel Agent, dan 1 Sport News Site. Traveloka.com berada pada posisi 4 dan pesaing terdekat yaitu Tiket.com berada pada posisi 8. Maka Traveloka.com merupakan perusahaan startup terbaik untuk Online Travel Agent di Indonesia.

Berdasarkan, Riset Adstensity sebuah aplikasi media menitoring khusus iklan-iklan TV mengalkulasi 10 merek paling banyak melakukan iklan di televisi dengan hasil pemantauan aktivitas penyiaran TVC/Ads spot yang tayang di 13 TV nasional selama 24 jam sehari, dapat dilihat pada Tabel 3 :

Tabel 3.

Merek Pengiklan Terbanyak Versi Nielsen.com

\begin{tabular}{ccc}
\hline No. & Merek & Total Pengeluaran \\
\hline 1. & Meikarta & Rp. 1,2 Triliun \\
2. & Traveloka.com & Rp. 871,6 Miliar \\
3. & Indomie & Rp. 767,2 Miliar \\
4. & Vivo Smartphone & Rp. 571,5 Miliar \\
5. & Samsung Smartphone & Rp. 564,1 Miliar \\
\hline $\begin{array}{l}\text { Sumber }: \text { Nielsen.com, } 2017 \\
\text { Berdasarkan riset } 15 \text { Merek pengiklan terbanyak versi Nielsen.com }\end{array}$ \\
Traveloka.com termasuk urutan 5 besar merek pengiklan terbanyak. \\
Traveloka.com merupakan jenis industri yang relatif baru tumbuh di Indonesia
\end{tabular}


yaitu e-commerce/digital business dan Traveloka.com mampu menggeser posisi Lazada dan Olx yang mendominasi di tahun 2016.

Iklan telah menjadi cara yang paling efektif bagi perusahaan untuk mengirimkan informasi produk untuk target konsumen. Cara utama untuk menarik konsumen adalah dengan menggunakan semua jenis dukungan, menggunakan selebriti, strategi pesan, dan strategi keterlibatan (Hermamalini \& Kurup, 2014:1). Cara utama untuk menarik konsumen adalah dengan menggunakan semua jenis dukungan, menggunakan selebriti penampilan, strategi pesan, dan strategi keterlibatan dukungan selebriti, efek iklan, dan iklan banding positif mempengaruhi minat beli.

Perusahaan pada masa sekarang ini berusaha melakukan iklan sebaik mungkin agar dapat menyebarkan informasi mengenai produk dan jasa yang mereka tawarkan (Vejacka et al., 2012 ). Beberapa studi terdapat hubungan antara iklan dengan keberlangsungan jangka panjang suatu perusahaan (Astrid et al., 2014). Kreatifitas dalam membuat iklan juga merupakan hal yang sangat penting, tidak hanya untuk strategi komunikasi semata namun juga sebagai sarana inovasi untuk mengingatkan konsumen akan produk yang ditawarkan (Gergely et al., 2013).

Penelitian yang dilakukan ( Nylasi et al., 2013 ) menemukan bahwa iklan tidak hanya dapat berpengaruh peningkatan penjualan jangka pendek, tetapi juga terhadap penjualan jangka panjang. Iklan sangat penting utamanya bagi brand yang baru maupun yang sudah ada di pasaran untuk tetap menyegarkan pikiran masyarakat. Shimp (2000) menjelaskan bahwa ada banyak tujuan 
melakukan iklan, beberapa diantaranya adalah informing atau memberikan informasi mengenai suatu produk, selanjutnya persuading membujuk dan reminding atau menyegarkan. Jika perusahaan mampu mengkomunikasikan produknya dengan baik melalui iklan, maka akan sebaliknya jika iklan yang dikomunikasikan kurang menarik atau bahkan tidak mendidik maka akan dapat menyebabkan konsumen tidak peduli terhadap iklan yang dilakukan. Terkadang juga suatu iklan walaupun menarik tidak mampu menumbuhkan keputusan pembelian oleh konsumen karena reponden hanya menganggapnya sebagai hiburan semata karena dalam pembelianya terdapat beberapa pertimbangan seperti adanya produk lain, harga dan lain-lain.

Sutisna (2001:101) menyatakan bahwa keterlibatan yang tinggi dari konsumen dalam suatu pembelian yang dilakukannya akan lebih tinggi hubungannya antar kepercayaan, sikap dan perilaku. Ketika konsumen mempunyai keterlibatan yang tinggi maka akan dapat menumbuhkan keputusan pembelian dan yang pertama konsumen harus percaya terhadap merek tersebut. Iklan dapat mempertahankan kesukaan merek dengan tujuan terhadap ketertarikan produk. Iklan yang menarik tentunya akan memiliki dampak positif terhadap suatu merek dan sebaliknya iklan yang kurang menarik tentunya akan dapat pula berdampak negatif terhadap perusahaan. Salah satunya adalah kurangnya minat beli yang akan berdampak terhadap keputusan pembelian, iklan yang tidak menarik yaitu dapat merugikan perusaahn karena perusahaan mengeluarkan anggaran yang besar dalam suatu iklan. 
Minat beli adalah suatu keinginan untuk membeli suatu produk atau jasa akibat pengaruh baik eksternal maupun internal dimana sebelumnya dilakukan evaluasi terhadap produk atau jasa yang akan di beli. (Helmi dkk., 2016) Menyatakan bahwa saat membeli produk bermerek, minat membeli konsumen mungkin tidak hanya dipengaruhi oleh persepsi merek tetapi dapat dipengaruhi oleh faktor lain salah satunya adalah iklan.

Minat beli mengacu pada kemungkinan konsumen membeli dari situs jual beli online manapun sebagai hasil kunjungan situs web (Naveen et al., 2016). Menurut Ling et al. (2010) munculnya beragam gerai ritel dan persaingan yang semakin ketet di pasar, situs online harus memahami orientasi belanja pelanggan untuk memaksimalkan niat pembeli online. Iklan menjadi kunci kesuksesan suatu situs jual beli online untuk menarik minat beli calon konsumen. Perusahaan Traveloka.com membuat iklan pada media televisi diharapkan mampu menimbulkan dan menumbuhkan minat beli pada calon konsumennya. Berbagai keberhasilan yang diraih suatu perusahaan tidak terlepas dari strategi pemasaran yang baik, begitu juga strategi pemasaran dari Traveloka.com adalah dengann menggunakan iklan. Iklan merupakan salah satu alternatif yang sering digunakan perusahaaan dalam melakukan bauran komunikasi pemasaran. Menurut Manfred et al. (2010) Efektivitas periklanan bergantung pada respon penggunaan terhadap pesan iklan dan sikap mereka terhadap periklanan. Dalam penelitian, Ying F. L. et al. (2015) menemukan bahwa pesan iklan berpengaruhi positif dan signifikan terhadap minat beli. Iklan dapat dilakukan melalui media elektronik maupun cetak, salah satunya adalah 
televisi. Televisi bersifat audiovisual, setiap gambar dan suara biasanya berisikan ajakan dan persuasi. Griffiths $(2012 ; 56)$ menambahkan bahwa televisi adalah media iklan yang paling menstimulasi secara visual. Iklan televisi adalah bentuk iklan yang mudah diakses dan paling berpengaruh. Model komunikasi pemasaran memiliki suatu pengaruh terhadap perusahaan, namun dalam penelitian ini komunikasi pemasaran memiliki pengaruh yang paling tinggi terhadap minat beli yaitu iklan dan word of mouth (pemasaran dari mulut ke mulut), Karena iklan dapat menyampaikan pesan kepada konsumen maupun calon konsumen mengenai suatu produk, merek maupun perusahaan dalam skala besar dan word of mouth dapat memberikan suatu pemahaman dari konsumen kepada calon konsumen mengenai pengalaman yang telah dialami oleh konsumen tersebut mengenai suatu produk, merek, maupun perusahaan.

Kotler dan Amstrong ( 2012:314 ) menyatakan bahwa harga merupakan jumlah uang yang dibebankan untuk produk atau jasa, atau lebih jelasnya adalah jumlah dari semua nilai yang diberikan oleh pelanggan untuk mendapatkan sebuah manfaat dengan memiliki atau menggunakan sebuah produk atau jasa, untuk pelanggan yang sensitive terhadap harga, harga yang relative murah biasanya adalah sumber kepuasan yang penting karena pelanggan akan mendapatkan value for money yang tinggi.

Menurut Nurhaeni (2014) konsumen melakukan kegiatan word of mouth untuk berbagai ide, opini, dan informasi kepada orang lain tentang produk jasa mereka beli atau gunakan. Melalui kegiatan seperti inilah konsumen dapat mengetahui kualitas dari suatu produk atau jasa. Berdasarkan penjelasan diatas, 
penelitian merasa perlu melakukan penelitian mengenai "Peran word of mouth memediasi hubungan iklan dan harga terhadap minat beli pada Traveloka.com"

Kotler dan keller (2012) yang mengemukakan bahwa minat beli merupakan perilaku konsumen dimana konsumen mempunyai keinginan dalam membeli atau memilih suatu produk, berdasarkan pengalaman dalam memilih, menggunakan dan mengkonsumsi atau bahkan menginginkan suatu produk. Studi Rizky dan Yasin (2014) membuktikan bahwa harga berpengaruh signifikan terhadap minat beli konsumsi. Hasil penelitian Arief (2017) dimana faktor pengaruh harga terhadap minat beli berpengaruh positif terhadap minat beli. namun, bertolah belakang dengan temuan penelitian yang dilakukan oleh Mirabi et al. (2015) yang dilakukan penelitian kepada konsumen produk genteng merek Bono menemukan bahwa price berpengaruh tidak signifikan terhadap minat beli.

Berdasarkan penelitian yang dilakukan oleh Raja Irfan Sabir et al. (2014) menemukan bahwa pesan iklan berpengaruh positif secara persial dan simulasi terhadap minat beli, hal selaras juga ditemukan dengan penelitian yang dilakukan oleh Wiliam Winata (2015) mendapatkan hasil pesan iklan berpengaruh positif secara simulasi dan parsial terhadap minat beli. penelitian.

Berbagai pernyataan yang telah dilakukan oleh penelitian-penelitian sebelumnya tentang hasil penemuan mengenai word of mouth, iklan, harga terhadap minat beli menunjukkan hasil yang berbeda-beda. Di satu sisi, mempunyai pengaruh positif, tetapi di sisi lain berpengaruh negative . 
Berdasarkan dua pendapat yang berbeda tersebut sehingga muncul reseach gap (perbedaan) hasil beberapa penelitian sebelumnya.

Menurut penelitian dari Keller Ed dan Fay Brand (2009) bahwa iklan terhadap word of mouth berpengaruh secara signifikan dikarenakan percakapan yang dipengaruh iklan dengan cara ini secara signifikan lebih mungkin melibatkan rekomendasi untuk membeli atau mencoba merek. Penelitian dari Ariama Chindella (2014) mengatakan bahwa iklan dan word of mouth berpengaruh signifikan terhadap minat beli. Secara parsial iklan iklan tidak berpengaruh signifikan terhadap minat beli sedangkan word of mouth secara parsial berpengaruh signifikan terhadap minat beli dan word of mouth dominan berpengaruh terhadap minat beli. Menurut penelitian dari wicaksono (2016) iklan berpengaruh signifikan terhadap word of mouth.

$\mathrm{H}_{1}$ : Variabel iklan memiliki pengaruh positif signifikan terhadap word of mouth

Zamil Ahmad M Ahmad (2011) mengatakan bahwa word of mouth merupakan bagian penting dari strategi pemasaran. Perusahaan harus membangun hubungan baik dengan pelanggannya untuk mendapatkan loyalitas mereka untuk berbicara tentang kebaikan perusahaan dan produk dengan itu word of mouth berpengaruh signifikan terhadap harga. Penelitian dari Lotulung (2015) mengatakan bahwa harga berpengaruh positif terhadap word of mouth. Harga berpengaruh signifikan terhadap word of mouth menurut penelitian dari Chinthya (2018).

$\mathrm{H}_{2}$ : Variabel harga memiliki pengaruh positif signifikan terhadap word of mouth 
Penelitian terdahulu Esthi Dwityanti (2008) penelitiannya dengan judul “Analisis Faktor-faktor Yang Mempengaruhi Minat Beli Konsumen Terhadap Layanan Internet Banking Mandiri (Studi Kasus Pada karyawan Departemen Pekerjaan Umum Jakarta) dimana iklan memiliki signifikan terhadap minat beli.

Iklan yang menarik dapat memperkuat minat dan keinginan konsumen dalam membeli suatu produk. Penelitian Dwityanti (2008:52) membuktikan bahwa variabel daya tarik iklan berpengaruh secara positif signifikan terhadap variabel minat beli.

Dalam penelitian, Ying F. L. et al. 2015 menemukan bahwa pesan iklan berpengaruh positif dan signifikan terhadap minat beli. Hasil penelitian tersebut selaras juga disampaikan oleh Hemamalini. K.S dan Shree Kala Kurup (2014); Adithya Rinaldy (2013) mendapatkan hasil bahwa pesan iklan berpengaruh positif dan signifikan terhadap minat beli.

$\mathrm{H}_{3}$ : Variabel iklan memiliki pengaruh positif signifikan tehadap minat beli

Hasil penelitian Hussin et al. (2013) dimana faktor produk yaitu harga secara signifikan berkolerasi dengan minat beli. serta konsisten pula dengan penelitian Martono dan Irini (2014) yang hasil membuktikan bahwa harga berpengaruh signifikan terhadap minat beli produk. Serta hasil penelitian Arief (2017) berpengaruh positif dan signifikan harga terhadap minat beli konsumen menunjukkan bahwa setiap peningkatan harga maka akan mengakibatkan meningkatnya kepuasan pelanggan untuk melakukan pembelian.

Penelitian lain dilakukan oleh Kristanto dan Wicaksono (2009:271) dan membuktikan bahwa variabel harga berpengaruh positif terhadap minat beli di 
Apotik Barito Farma Sukoharjo. Hasil penelitian dari Rruri dan Hendra (2017) dimana harga secara persial berpengaruh signifikan terhadap minat beli. Dalam penelitian Febby (2014) bahwa terdapat pengaruh harga efektifitas iklan internet dan promosi yang positif dan signifikan terhadap minat beli konsumen. Penelitian dari hetty (2015) mengatakan bahwa harga berpengaruh signifikan terhadap minat beli.

$\mathrm{H}_{4}$ : Variabel harga memiliki pengaruh positif signifikan terhadap minat beli.

Menurut penelitian dari kalele dkk. (2015) menunjukan bahwa word of mouth berpengaruh signifikan terhadap minat beli di PT. Sinar Galesong Mandiri. Menurut Umamy et al. (2016), minat beli dipengaruhi oleh rekomendasi, saran dan review yang diterima responden atau calon konsumen. Semakin sering calon konsumen mengumpulkan informasi dengan kredibilitas tinggi dan kualitas informasi yang baik, maka akan meningkatkan kecenderungan terhadap minat beli. pengaruh posistif dari Word Of Mouth pada minat beli telah ditunjukkan oleh penelitian dari Kumala (2012).

$\mathrm{H}_{5}$ : Variabel Word Of Mouth memiliki pengaruh positif signifikan terhadap minat beli

Menurut penelitian dari Kumala (2012) mengenai pengaruh word of mouth terhadap minat beli pada konsumen Tune Hotels Kuta Bali. Hasil penelitian yaitu menunjukkan bahwa word of mouth memiliki pengaruh yang signifikan terhadap minat beli. Seperti pendapat yang dikemukakan oleh Saptaningsih (2008), dalam Kumala (2012) bahwa fenomena word of mouth diyakini bisa mendorong minat beli konsumen, bisa mempengaruhi komunitas, efisiensi karena tidak memerlukan 
budged yang besa (low cost), bisa menciptakkan image positif bagi produk, dan bisa menyentuh emosi konsumen.

$\mathrm{H}_{6}$ : word of mouth memediasi hubungan iklan dan harga dengan minat beli

\section{METODE PENELITIAN}

Penelitin ini dilakukan pada e-commerce situs yang menjual tiket pesawat dan penginapan yaitu Traveloka.com. Lokasi dipilih di Kota Denpasar karena Denpasar merupakan ibu kota provinsi sehingga menjadi pusat banyak aktivitas seperta sebagai pusat bisnis dan perdagangan, pusat pemerintah, pusat pendidikan, dan pusat kesempatan kerja. Kondisi ini menarik banyak penduduk dan pusat kesempatan kerja. Kota Denpasar memiliki potensi ekonomi yang baik dan ratarata memiliki tingkat pendidikan yang tinggi. Masyarakatnya yang setiap hari beraktifitas dengan menggunakan internet ini bisa dilihat dari jumlah penggunan internet di Kota Denpasar pada tahun 2017 mencapai 54,23 persen. Selain itu, kesibukan masyarakat diperkotaan sangat padat dan memudahkan merek untuk mengakses suatu situs untu berbelanja.

Populasi dalam penelitian ini adalah calon konsumen Traveloka.com di Kota Denpasar yang jumlahnya tidak dapat dihitung secara pasti. Penelitian ini menggunakan 17 indikator sehingga sampel yang diperlukan minimal 85 (5x17) dan maksimal 170 (10x17). Penelitian ini menggunakan 100 responden yang merupakan 17 indikator dikali 8 yang berarti sudah memenuhi kriteria minimal 85 responden dan maksimal 170 responden. Model dapat dinyatakan dalam bentuk persamaan atau diagram jalur sehingga ada yang menamakan system persamaan simulasi, atau juga ada yang menyebut model structural. 
Substruktur 1

$$
\mathrm{M}=\beta \mathrm{X}+\varepsilon_{1}
$$

Substruktur 2

$$
\mathrm{Y}=\beta \mathrm{X}+\beta M+\varepsilon_{2}
$$

\section{HASIL DAN PEMBAHASAN}

Data yang telah diolah dan dihitung akan menunjukkan hasil analisis seperti Tabel 4 dan Tabel 5.

Tabel 4. Hasil Analisis Jalur Persamaan Regresi 1

\begin{tabular}{lccccc}
\hline Model & $\begin{array}{c}\text { Unstandardized } \\
\text { Coefficients } \\
\text { B }\end{array}$ & Std. Error & $\begin{array}{c}\text { Standardized } \\
\text { Coefficients } \\
\text { Beta }\end{array}$ & T & Sig. \\
\hline 1 (Constant) & $-0,655$ & 0,407 & & $-1,610$ & 0,111 \\
Iklan & 0,539 & 0,128 & 0,371 & 4,201 & 0,000 \\
Harga & 0,566 & 0,114 & 0,454 & 5,140 & 0,000 \\
& & & & Sig F: & \\
R12: 0,299 & & F & & 0,000 & \\
& & Statistik: & & & \\
& 61,916 & &
\end{tabular}

Sumber: Data diolah, 2018

Hasil analisis jalur substruktur 1 telah disajikan pada Tabel 4, maka persamaan strukturalya adalah sebagai berikut:

$\mathrm{Y} 1=\beta_{\mathrm{y} 1 \mathrm{X} 1}+\beta \mathrm{y}_{1} \mathrm{X}_{2}+\mathrm{e}_{1}$

$\mathrm{Y} 1=0,371 \mathrm{X} 1+0,454 \mathrm{X}_{2}$

Nilai $\beta 1$ adalah sebesar 0,371 memiliki arti bahwa iklan berpengaruh positif terhadap word of mouth, dengan kata lain jika iklan meningkat maka akan mengakibatkan peningkatan pada word of mouth Traveloka.com sebesar 0,371

Nilai $\beta 2$ adalah sebesar 0,454 memiliki arti bahwa harga berpengaruh positif terhadap word of mouth, dengan kata lain jika harga sesuai dengan 
konsumen inginkan maka meningkatkan word of mouth pada Traveloka.com sebesar 0,454 .

Tabel 5.

Hasil Analisis Jalur Persamaan Regresi 2

\begin{tabular}{lccccc}
\hline Model & $\begin{array}{c}\text { Unstandardized } \\
\text { Coefficients }\end{array}$ & & $\begin{array}{c}\text { Standardized } \\
\text { Coefficients }\end{array}$ & & T \\
\cline { 2 - 4 } 1 (Constant) & B & Std. Error & Beta & & \\
Iklan & $-0,018$ & 0,321 & & 0,956 & 0,956 \\
Harga & 0,296 & 0,109 & 0,223 & 2,719 & 0,008 \\
Word of mouth & $-0,351$ & 0,100 & 0,298 & 3,494 & 0,001 \\
R22: 0,216 & $-0,371$ & 0,079 & 0,408 & 4,690 & 0,000 \\
& & & & Sig F: & \\
S & & F & & 0,000 & \\
\hline
\end{tabular}

Sumber: Data diolah, 2018

Hasil analisis jalur substruktur 2 telah disajikan pada Tabel 5 maka persamaan strukturalnya adalah sebagai berikut:

$\mathrm{Y} 2=\beta \mathrm{y}_{2} \mathrm{X}_{1}+\beta \mathrm{y}_{2} \mathrm{X}_{2}+\beta \mathrm{y}_{2} \mathrm{y}_{1}+\mathrm{e}_{2}$

$\mathrm{Y} 2=(0,223) \mathrm{X}_{1}+(0,298) \mathrm{X}_{2}+(0,408) \mathrm{y}_{1}$

Nilai $\beta 3$ adalah sebesar 0,223 memiliki arti bahwa iklan berpengaruh positif terhadap minat beli, dengan kata lain jika faktor iklan meningkat maka akan mengakibatkan peningkatan pada minat beli Traveloka..com sebesar 0,223 . Nilai $\beta 4$ adalah sebesar 0,298 memiliki arti bahwa harga berpengaruh positif terhadap minat beli, dengan kata lain jika faktor harga sesuai dengan konsumen akan mengakibatkan peningkatan pada minat beli pada Traveloka.com sebesar 0,298. Nilai $\beta 5$ adalah sebesar 0,408 memiliki arti bahwa word of mouth berpengaruh positif terhadap minat beli, dengan kata lain jika faktor word of mouth meningkat maka akan mengakibatkan peningkatan pada minat beli Traveloka.com sebesar 0,408 . 
Hasil pengujian pada Tabel 4. diperoleh nilai koefisien signifikan $0,001 \leq$ 0,05. Hasil tersebut menunjukkan bahwa Iklan, dan Harga berpengaruh secara simultan terhadap word of mouth. Hasil pengujian pada Tabel 5 diperoleh nilai koefisien signifikan $0,025 \leq 0,05$. Hasil tersebut menunjukan bahwa Iklan, Harga dan Word of mouth berpengaruh secara simultan dan signifikan terhadap Minat beli .

Hasil analisis pengaruh iklan terhadap word of mouth pada Tabel 4 diperoleh nilai koefisien beta sebesar 0,000 dengan nilai signifikan t $0,000<0,05$, sehingga $\mathrm{H}_{0}$ ditolak dan $\mathrm{H}_{1}$ diterima. Hasil tersebut menunjukan bahwa iklan berpengaruh positif dan signifikan terhadap word of mouth. Hal ini dapat diartikan iklan berpengaruh positif secara signifikan terhadap word of mouth Traveloka.com yang artinya dimana percakapan mengenai produk yang mengambil tempat dalam komunikasi luas yaitu seberapa banyak orang membicarakan suatu produk maka akan tersebar luas informasi tersebut.

Hasil analisis pengaruh likuiditas terhadap return saham pada Tabel 5 diperoleh nilai koefisien beta sebesar 0,000 dengan nilai signifikan t $0,000<0,05$, sehingga $\mathrm{H}_{0}$ ditolak diterimdan $\mathrm{H}_{1}$ diterima. Hasil tersebut menunjukan bahwa

Hasil analisis pengaruh struktur modal terhadap profitabilitas pada Tabel 4 diperoleh nilai koefisien beta sebesar 0,008 dengan nilai signifikansi t 0,008< 0,05, sehingga $\mathrm{H}_{3}$ ditolak dan $\mathrm{H}_{1}$ diterima. Hasil tersebut menunjukkan bahwa iklan berpengaruh positif dan signifikan terhadap minat beli.

Hasil analisis pengaruh struktur modal terhadap harga pada Tabel 5 diperoleh nilai koefisien beta sebesar 0,001 dengan nilai signifikan t 0,001<0,05, 
sehingga $\mathrm{H}_{0}$ ditolak $\mathrm{H}_{4}$ diterima. Hasil tersebut menunjukkan bahwa harga berpengaruh positif dan signifikan terhadap minat beli.

Hasil analisis pengaruh profitabilitas terhadap word of mouth pada Tabel 5 diperoleh nilai koefisien beta sebesar 0,000 dengan nilai signifikan t $0,000<0,05$, sehingga $\mathrm{H}_{0}$ ditolak dan $\mathrm{H}_{5}$ ditermia. Hasil tersebut menunjukan bahwa word of mouth berpengaruh positif dan signifikan terhadap minat beli.

Pengaruh variabel iklan (X1) terhadap variabel harga (X2) dengan variabel word of mouth (Y1) sebagai variabel mediasi, sebagai berikut:

Pengaruh tidak langsung $=\mathrm{Px}_{1} \mathrm{y}_{1} \mathrm{x} \mathrm{Py}_{1} \mathrm{y}_{2}$

$$
\begin{aligned}
& =0,371 \times 0,408 \\
& =0,151
\end{aligned}
$$

Pengaruh variabel Harga (X2) terhadap variabel minat beli (Y2) dnegan variabel word of mouth (Y1) sebagai variabel mediasi, sebagai berikut: Pengaruh tidak langsung $=\mathrm{Px}_{2} \mathrm{y}_{1} \mathrm{x} \mathrm{Py}_{1} \mathrm{y}_{2}$

$$
\begin{aligned}
& =0,454 \times 0,408 \\
& =0,185
\end{aligned}
$$

Pengaruh variabel iklan (X1) terhadap variabel minat beli (Y2) melalui variabel word of mouth (Y1), sebagai berikut:

Pengaruh total $=\mathrm{Px}_{1} \mathrm{y}_{2}+\left(\mathrm{Px}_{1} \mathrm{y}_{1} \mathrm{x} \mathrm{Py}_{1} \mathrm{y}_{2}\right)$

$$
\begin{aligned}
& =0,223+0,185 \\
& =0,408
\end{aligned}
$$

Pengaruh variabel harga (X2) terhadap variabel minat beli (Y2) melalui variabel word of mouth (Y1), sebagai berikut:

Pengaruh total $=\mathrm{Px}_{2} \mathrm{y}_{2}+\left(\mathrm{Px}_{2} \mathrm{y}_{1} \mathrm{x}_{\left.\mathrm{P}_{1} \mathrm{y}_{2}\right)}\right.$ 


$$
\begin{aligned}
& =0,298+0,185 \\
& =0,483
\end{aligned}
$$

Standard error telah dihitung, maka didapatkan hasil pengaruh error1 sebesar 0,153 dan pengaruh error2 sebesar 0,027 . Perhitungan nilai koefisien determinasi total adalah sebagai berikut:

$$
\mathrm{R}^{2} \mathrm{~m}=1-\left(\mathrm{Pe}_{1}\right)^{2}\left(\mathrm{Pe}_{2}\right)^{2}
$$

$$
\begin{aligned}
& =1-(0,662)^{2}(0,564)^{2} \\
& =1-(0,43824)(0,318096) \\
& =1-0,13940239104 \\
& =0,860
\end{aligned}
$$

Nilai koefisien determinasi total sebesar 0,860 yang berarti bahwa sebesar 86,0 persen variasi minat beli dipengaruhi oleh iklan, harga dan word of mouth, sedangkan sisanya sebesar 0,13940239104 persen dijelaskan oleh faktor lain yang tidak dimasukkan ke dalam model.

Hasil pada Tabel 7. menunjukkan pengaruh langsung iklan terhadap minat beli sebesar 0,223 , sedangkan pengaruh tidak langsung yang dimediasi oleh word of mouth menunjukkan nilai koefisien beta sebesar 0,151. Hasil tersebut membuktikan bahwa word of mouth mampu memediasi pengaruh iklan terhadap minat beli dengan pengaruh total yang diperoleh sebesar 0,374 .

\section{Tabel 6.}

Pengaruh Langsung, Pengaruh Tidak Langsung serta Pengaruh Total Iklan (X1), Word of mouth (Y1) dan Minat Beli (Y2)

\begin{tabular}{llll}
\hline Pengaruh & Pengaruh & Pengaruh tidak langsung melalui & Pengaruh Total \\
Variabel & Langsung & Profitabilitas & \\
& & Y1 $=($ Px1y1 x Py1y2 $)$ & \\
\hline
\end{tabular}




\begin{tabular}{lccc}
\hline $\mathrm{X} 1 \rightarrow \mathrm{Y} 1$ & 0,371 & - & 0,371 \\
$\mathrm{X} 1 \rightarrow \mathrm{Y} 2$ & 0,223 & 0,151 & 0,374 \\
$\mathrm{Y} 1 \rightarrow \mathrm{Y} 2$ & 0,408 & - & 0,408 \\
\hline
\end{tabular}

Sumber: Data diolah, 2018

Table 7.

Pengaruh Langsung, Pengaruh Tidak Langsung serta Pengaruh TotalHarga(X2), Word of Mouth (Y1) dan Minat Beli (Y2)

\begin{tabular}{|c|c|c|c|c|}
\hline $\begin{array}{l}\text { Pengaruh } \\
\text { Variabel }\end{array}$ & $\begin{array}{l}\text { Pengaruh } \\
\text { Langsung }\end{array}$ & & $\begin{array}{l}\text { angsung melalui } \\
\text { y1y2) }\end{array}$ & Pengaruh Total \\
\hline $\mathrm{X} 2 \rightarrow \mathrm{Y} 1$ & & 0,454 & - & 0,454 \\
\hline $\mathrm{X} 2 \rightarrow \mathrm{Y} 2$ & & 0,298 & 0,185 & 0,483 \\
\hline $\mathrm{Y} 1 \rightarrow \mathrm{Y} 2$ & & 0,408 & - & 0,408 \\
\hline
\end{tabular}

Sumber:Data diolah, 2018

Hasil pada Tabel 7. menunjukkan pengaruh langsung harga terhadap minat beli sebesar 0,298, sedangkan pengaruh tidak langsung yang dimediasi oleh word of mouth menunjukkan nilai koefisien beta sebesar 0,185. Hasil tersebut membuktikan bahwa word of mouth mampu memediasi pengaruh harga terhadap minat beli dengan pengaruh total yang diperoleh sebesar 0,483 . yang diperoleh sebesar 0,4

Pengaruh Iklan terhadap Harga yang di memediasi oleh Word of Mouth

$$
\begin{aligned}
& \mathrm{Z}=\frac{\mathrm{a} 1 \mathrm{~b}}{\sqrt{a 1^{2} s_{\mathrm{b}}{ }^{2}+b^{2} s a 1^{2}+s a 1^{2} s_{b}^{1}}} \\
& Z=\frac{(0,371)(0,408)}{\sqrt{(0,371)^{2}}(0,079)^{2}+(0,408)^{2}(0,128)^{2}+(0,128)^{2}(0,079)^{2}} \\
& Z=\frac{0,1514}{\sqrt{0,0009+0,00027+0,0001}} \\
& Z=\frac{0,1514}{0,060734} \\
& Z=2,4923
\end{aligned}
$$


Berdasarkan hasil uji sobel dalam penelitian ini menunjukkan bahwa hasil tabulasi $\mathrm{Z}=2,4923>1,96$. Hasil tersebut memiliki arti bahwa word of mouth memediasi pengaruh iklan terhadap harga.

Pengaruh Harga terhadap Minat Beli yang dimediasi oleh Word of Mouth

$$
\begin{aligned}
& Z=\frac{a_{2} b}{\sqrt{a_{2}^{2} s_{b}^{2}+b^{2} s a_{2}^{2}+s a_{2}^{2} s_{b}^{2}}}=\ldots \ldots \ldots \ldots \ldots \ldots \ldots \ldots . .(10) \\
& Z=\frac{(0,586)(0,372)}{\sqrt{(0,454)^{2}}(0,079)^{2}+(0,408)^{2}(0,114)^{2}+(0,114)^{2}(0,079)^{2}} \\
& Z=\frac{0,1852}{\sqrt{0,0013+0,0022+0,001}} \\
& Z=\frac{0,1852}{0,059421} \\
& Z=3,1173
\end{aligned}
$$

Berdasarkan hasil uji sobel dalam penelitian ini menunjukkan bahwa hasil tabulasi $Z=3,1173>1,96$. Hasil tersebut memiliki arti bahwa word of mouth memediasi pengaruh harga terhadap minat beli.

Formula VAF yaitu :

$$
\mathrm{VAF}=\frac{\text { Pengaruh Tidak Langsung }(\text { Indirect Effect })}{\text { Pengaruh Total }(\text { Total Effect })}
$$

Berdasarkan tabel 8. di atas, terlihat hasil VAF yaitu 40,37 persen, maka dapat disimpulkan dengan berpedoman pada kriteria : (1) jika nilai VAF di atas 80 persen, maka menunjukkan peran pemediasi penuh (full mediation), (2) jika VAF bernilai di atas 20-80 persen, maka dapat dikategorikan sebagai pemediasi parsial, (3) jika VAF kurang dari 20 persen, penelitian dapat menyimpulkan bahwa hamper tidak ada efek mediasi (Hair dkk., 2013). 
Tabel 8.

Uji VAF

\begin{tabular}{ll}
\hline \multicolumn{1}{c}{ Keterangan Pengaruh } & \multicolumn{1}{c}{ Hasil Perhitungan } \\
\hline $\begin{array}{l}\text { Pengaruh Tidak Langsung = Iklan } \rightarrow \text { word of } \\
\text { mouth }=0,371 * \text { word of mouth } \rightarrow \text { Minat Beli }\end{array}$ & 0,151 \\
$=0,408$ & \\
$\begin{array}{l}\text { Pengaruh Langsung } \\
\text { Iklan } \rightarrow \text { Minat Beli } ; \text { tanpa memasukkan word } \\
\text { of mouth sebagai pemediasi }=0,223\end{array}$ & 0,223 \\
Pengaruh Total $=0,223+0,151$ & \\
VAF $=$ Pengaruh tidak langsung / pengaruh & 0,374 \\
total $=0,151 / 0,374$ & $0,40374=$ atau $40,37 \%$ \\
\hline Sumber $:$ Data diolah, 2018 &
\end{tabular}

Berpedoman pada kriteria penguji mediasi VAF, maka dapat disimpulkan VAF sebesar 40,37 persen, termasuk dalam kategori pemediasi parsial. Hipotesis dalam penelitian ini iklan berpengaruh positif dan signifikan terhadap word of mouth. Berdasarkan hasil pengujian pengraruh iklan (X1) dan word of mouth (Y1) yang ditunjukkan pada Tabel 4, diketahui bahwa tingkat signifikansi t uji sebesar 0,000 yang menunjukkan angka lebih kecil daripada taraf nyata dalam penelitian ini yaitu $\alpha=0,05$ dengan nilai koefisien beta 0,371 . Hal ini menunjukkan bahwa iklan berpengaruh positif dan signifikan terhadap word of mouth. Hasil ini menerima $\mathrm{H}_{1}$ yakni iklan berpengaruh positif dan signifikan terhadap word of mouth.

Menurut penelitian dari Keller Ed dan Fay Brand (2009) bahwa iklan terhadap word of mouth berpengaruh secara signifikan dikarenakan percakapan yang dipengaruh iklan dengan cara ini secara signifikan lebih mungkin melibatkan rekomendasi untuk membeli atau mencoba merek bila dibandingkan dengan disuse word of mouth tentang merek.

Hasil penelitian ini mendukung hasil penelitian sebelumnya yang dilakukan oleh Ariama Chindella (2014) mengatakan bahwa iklan dan word of mouth 
berpengaruh signifikan terhadap minat beli. secara parsial iklan iklan tidak berpengaruh signifikan terhadap minat beli sedangkan word of mouth secara parsial berpengaruh signifikan terhadap minat beli dan word of mouth dominan berpengaruh terhadap minat beli. Menurut penelitian dari wicaksono (2016) iklan berpengaruh signifikan terhadap word of mouth.

Hipotesis dalam penelitian ini iklan berpengaruh positif dan signifikan terhadap minat beli. Berdasarkan hasil pengujian pengaruh iklan (X1) terhadap minat beli (Y2) yang ditunjukkan pada Tabel 5, diketahui bahwa tingkat signifikansi t uji sebesar 0,008 yang menunjukkan angka lebih besar dari taraf nyata dalam penelitian ini yaitu $\alpha=0,05$ dengan nilai koefisien beta sebesar 0,223. Hal ini menunjukkan bahwa iklan berpengaruh negatif dan tidak signifikan pada minat beli. Hasil ini menolak $\mathrm{H}_{2}$ yakni iklan berpengaruh positif dan signifikan terhadap minat beli.

Hasil Dalam penelitian terdahulu Esthi Dwityanti (2008) penelitiannya dengan judul “Analisis Faktor-faktor Yang Mempengaruhi Minta Beli Konsumen Terhadap Layanan Internet Banking Mandiri (Studi Kasus Pada karyawan Departemen Pekerjaan Umum Jakarta) dimana iklan memiliki signifikan terhadap minat beli. Iklan yang menarik dapat memperkuat minat dan keinginan konsumen dalam membeli suatu produk. Penelitian Dwityanti (2008:52) membuktikan bahwa variabel daya tarik iklan berpengaruh secara positif signifikan terhadap variabel minat beli.

Safrena Juwita Larasati (2012) dan Ying Fang Lai et al. 2015 menemukan bahwa pesan iklan berpengaruh positif dan signifikan terhadap minat beli. Hasil 
penelitian tersebut selaras juga disampaikan oleh Hemamalini. K.S dan Shree Kala Kurup (2014); Adithya Rinaldy (2013) mendapatkan hasil bahwa pesan iklan berpengaruh positif dan signifikan terhadap minat beli. Mai Ngoc Khuong dan Truong Duc Nguyen (2015) dalam penelitiannya menemukan hasil bahwa pesan iklan berpengaruh positif dan signifikan terhadap minat beli.

Hipotesis dalam penelitian ini harga berpengaruh positif dan signifikan terhadap word of mouth. Berdasarkan hasil pengujian pengaruh harga (X2) terhadap word of mouth (Y1) yang ditunjukkan pada Tabel 4, diketahui bahwa tingkat signifikansi $\mathrm{t}$ uji sebesar 0,000 yang menunjukkan angka lebih kecil daripada taraf nyata dalam penelitian ini yaitu $\alpha=0,05$ dengan nilai koefisien beta harga sebesar 0,454. Hal ini menunjukkan bahwa harga berpengaruh negatif dan signifikan terhadap word of mouth. Hasil ini menolak $\mathrm{H}_{3}$ yakni harga berpengaruh positif dan signfikan terhadap word of mouth.

Zamil Ahmad M Ahmad (2011) mengatakan bahwa word of mouth merupakan bagian penting dari strategi pemasaran. Perusahaan harus membangun hubungan baik dengan pelanggannya untuk mendapatkan kesetian mereka untuk berbicara tentang kebaikan perushaan dan produk dengan itu word of mouth berpengaruh sifnifikan terhadap harga. Penelitian dari Lotulung (2015) mengatakan bahwa harga berpengaruh positif terhadap word of mouth. Harga berpengaruh signifikan terhadap word of mouth menurut penelitian dari Chinthya (2018).

Hipotesis dalam penelitian ini harga berpengaruh negatif dan signifikan terhadap minat beli. Berdasarkan hasil pengujian pengaruh harga (X2) terhadap 
minat beli (Y2) yang ditunjukkan pada Tabel 5, diketahui bahwa tingkat signifikansi t uji sebesar 0,001 yang menunjukkan angka lebih kecil daripad taraf nyata dalam penelitian ini yaitu $\alpha=0,05$ dengan nilai koefisien beta sebesar 0,298. Hal ini menunjukkan bahwa harga berpengaruh negatif dan signifikan terhadap minat beli. Hasil ini menerima $\mathrm{H}_{4}$ yakni harga berpengaruh positif dan signifikan terhadap minat beli.

Hasil penelitian Hussin et al. (2013) dimana foktor produk yaitu harga secara signifikan berkolerasi dengan minat beli. serta konsisten pula dengan penelitian Martono dan Irini (2014) yang hasil membuktikan bahwa harga berpengrauh signifikan terhadap minat beli produk. Serta hasil penelitian Arief (2017) berpengaruh positif dan signifikan harga terhadap minat beli konsumen menunjukkan bahwa setiap peningkatan harga maka akan mengakibatkan meningkatnya kepuasan pelanggan untuk melakukan pembelian.

Penelitian lain dilakukan oleh Kristanto dan Wicaksono (2009:271) dan membuktikan bahwa variabel harga berpengaruh positif terhadap minat beli di Apotik Barito Farma Sukoharjo. Hasil penelitian dari Rruri dan Hendra (2017) dimana harga secara persial berpengaruh signifikan terhadap minat beli. Dalam penelitian Febby (2014) bahwa terdapat pengaruh harga efektifitas iklan internet dan promosi yang positif dan signifikan terhadap minatbeli konsumen. Penelitian dari hetty (2015) mengatakan bahwa harga berpengaruh signifikan terhadap minat beli.

Hipotesis dalam penelitian ini word of mouth berpengaruh positif dan signifikan terhadap minat beli. Berdasarkan hasil pengujian pengaruh word of 
mouth (Y1) pada miant beli (Y2) yang ditunjukkan pada Tabel 5, diketahui bahwa tingkat signifikansi t uji sebesar 0,000 yang menunjukkan angka lebih kecil daripada taraf nyata dalam penelitian ini yaitu $\alpha=0,05$ dengan nilai koefisian beta 0,408. Hal ini menunjukkan bahwa word of mouth berpengaruh negatif dan signifikan terhadap minat beli. Hasil ini menolak $\mathrm{H}_{5}$ yakni word of mouth berpengaruh positif dan signifikan terhadap minat beli.

Hasil penelitian Kalele dkk. (2015) menunjukan bahwa word of mouth berpengaruh signifikan terhadap minat beli di PT. Sinar Galesong Mandiri. Menurut Umamy et al.(2016), minat beli dipengaruhi oleh rekomendasi, saran dan review yang diterima responden atau calon konsumen.semakin sering calon konsumen mengumpulkan informasi dengan kredibilitas tinggi dan kualitas informasi yang baik, maka akan meningkatkan kecenderungan terhadap minat beli. pengaruh posistif dari Word Of Mouth pada minat beli telah ditunjukkan oleh penelitian dari Kumala (2012).

Peran word of mouth memediasi pengaruh iklan dan harga terhadap minat beli telah diuji dalam penelitian ini. Hasil uji pengaruh iklan terhadap minat beli semula bernilai 0,223 , kemudian setelah adanya word of mouth sebagai variabel mediasi, nilai pada pengaruh iklan dan harga terhadap minat beli meningkat menjadi sebesar 0,008 . Uji sobel yang telah dihitung memperoleh nilai koefisien z sebesar 3,11>1,96.

Berdasarkan hasil analisis jalur, dapat disimpulkan bahwa word of mouth mampu memediasi pegaruh iklan dan harga terhadap minat beli karena iklan memiliki pengaruh yang signifikan terhadap minat beli, sedangkan iklan dan harga terhadap 
word of mouth dan word of mouth terhadap minat beli memiliki pengaruh yang signifikan terhadap minat beli oleh karena itu word of mouth mampu memediasi pengaruh iklan dan harga terhadap minat beli.

Menurut penelitian dari Kumala (2012) mengenai pengaruh word of mouth terhadap minat beli pada konsumen Tune Hotels Kuta Bali. Hasil penelitian yaitu menunjukkan bahwa word of mouth memiliki pengaruh yang signifikan terhadap minat beli.seperti pendapat yang di kemukakan oleh Saptaningsih (2008), dalam Kumala (2012) bahwa fenomena word of mouth diyakini bisa mendorong minat beli konsumen, bisa mempengaruhi komunitas, efisiensi karena tidak memerlukan budged yang besa (low cost), bisa menciptakkan image positif bagi produk, dan bisa menyentuh emosi konsumen.

\section{SIMPULAN DAN SARAN}

Iklan berpengaruh positif dan signifikan terhadap word of mouth. Nilai iklan yang tinggi akan menjadi nilai positif bagi perusahaan dalam menghasilkan word of mouth. Iklan berpengaruh positif dan signifikan terhadap minat beli artinya promosi yang dilakukan oleh Traveloka.com melalui media televise sudah tepat, karena penyampaian informasi yang ditampilkan dapat meyakinkan calon konsumen tentang keunggulan produk yang diiklankan sehingga akan dapat mempengaruhi calon konsumen untuk membeli produk tersebut.

Harga berpengaruh positif dan signifikan terhadap word of mouth . hasil ini berarti bahwa dengannya ditetapkanya biaya Tarveloka.com, dapat meningkatkan word of mouth konsumen Traveloka.com. Harga berpengaruh dan signifikan 
terhadap minat beli. jadi jika harga naik maka keputusan pembelian akan turun dan sebaliknya jika harga turun makan keputusan pembelian akan naik.

Word of mouth berpengaruh positif dan signifikan terhadap minat beli. komunikasi word of mouth yang dilakukan meliputi membicarakan, mempromosikan dan merekomendasikan Traveloka.com kepada orang lain baik itu kepada teman maupun saudara. Word of Mouth Memediasi Pengaruh Iklan dan Harga terhadap Minat beli sehingga dapat dihasilkan penyebaran informasi word of mouth terhadap minat beli setelah dilakukan survey diatas maka didapat bahwa segala dimensi merupakan bagian kesuksesan suatu word of mouth untuk menciptakan minat beli.

Bagi perusahaan hendaknya hasil penelitian ini dapat menjadi bahan pertimbangan untuk menaikkan pembelian perusahaan. Traveloka.com dapat menunjukkan prestasi yang baik dan konsumen mendapatkan informasi yang benar adanya. Bagi konsumen penelitian ini diharapkan dapat memberikan infomasi yang menjadi bahan pertimbangan dalam menentukan Bagi peneliti selanjutnya yang ingin meneliti mengenai minat beli, tambahkan variabel lain sebagai variabel bebas, dan gunakan variabel lain sebagai variabel mediasi sehingga didapatkan indikator lain yang memiliki hubungan dengan minat beli.

\section{REFERENSI}

Ariama, Chindella. (2018) . Pengaruh Iklan dan Word of mouth terhadap Minat Belanja Online Dengan Aplikasi Lazada . E-Jurnal Administrasi Bisnis, Vol 2, No 6. (2018) : 487.

Arief. A.S. (2017). Pengaruh Harga, Promosi, dan Kualitas Produk terhadap Minat Beli Konsumen. Jurnal Manajemen.Vol. 2. No. 1. Hal. 2-3

Chinthya. (2018). Pengaruh WOM, Harga dan Kualitas Layanan Terhadap Keputusan Pembelian. Vol. 2 No.1. Hal 4 
Dwityanti, Esthi. (2008). Analisis Faktor-Faktor Yang Mempengaruhi Minat Beli Konsumen Terhadap Layanan Internet Banking Mandiri. Semarang: Program Pasca Sarjana Universitas Diponegoro.

Dwityanti, E. (2008). Analisis Faktor-faktor yang Mempengaruhi Minat Beli Konsumen terhadap Layanan Internet Banking Mandiri (Studi Kasus Pada Karyawan Departemen Pekerjaan Umum Jakarta). Program Studi Magister Manajemen Program Pasca Sarjana Universitas Diponegoro, Semarang. Tesis.

Gergely. (2013). Ad agency professiona Is mental metodels of advertising creativity. European Journal of Marketing, 47(10):1691-1710.

Griffiths, Andrew. (2012). Iklan Powerful Untuk Bisnis Anda Berawal Dari Buku Ini. Jakarta : Tangga Pustaka

Hemamalini \& Kurup. (2014). Effectiveness of Television Advertisement on Purchase Intention. Vol. 3, No.2 .

Hetty Sri Wardani. (2015). Pengaruh Kualitas Produk Dan Harga Terhadap Minat Beli Konsumen Muslim Pada Jaizah Boutique Tlogosari Semarang. Vol. 2 No. 1. Hal 24.

Helmi, M. S., Arrafiqurrahman, Hamdi, S. M. (2016). Faktor-Faktor Yang Mempengaruhi Minat Beli Konsumen Pada Cv Master Pasir Pengaraian Kabupaten Rokan Hulu. $\quad$ E-Journal Mahasiswa Prodi Manajemen Fakultas Ekonomi Universitas Pengaraian, 3(1) : 2-16

Hussin S. R., Hashim, H., Yusof, R.N., Alias, N. N. (2013). Relationship between Product Factors, Advertising, and Purchase Intention of Halal Cosmetic. ISSN: 012

Kalele Biliclinton. (2015). Pengaruh Word Of Mouth,Daya Tarik Iklan,Persepsi Harga dan Kualitas Produk Terhadap Minat Beli Motor Suzuki Satria Pada PT. Sinar Galesong Mandiri.Vol.3 No. 3 Sept (2015), Hal.451-462.

Kristanto, Yuni., Wicaksono, D.W. Pengaruh Harga dan Kualitas Pelayanan Terhadap Minat Beli Konsumen di Apotek Barito Farma Sukoharjo. Bisnis dan Kewirausahaan,Vol.2 No,3 April 2009-ISSN 1979-0333

Kotler, Philip and Gary Armstrong. (2012). Prinsip-prinsipPemasaran. Edisi 13. Jilid 1. Jakarta: Erlangga.

Kumala, O.B. (2012). Pengaruh Word Of Mouth Terhadap Minat Beli Konsumen pada Tune Hotels Kuta Bali.Skripsi. Universitas Indonesia. 
Lotulung. (2015). Pengaruh Kualitas Produk Harga, dan WOM Terhadap Keputusan Pembelian Handphone Evercoss Pada CV. Tristar Jaya Globalindo Manado. Jurnal EMBA. Vol 3. (2015), hal 817.

Lubis, Mila. (2017). Belanja Iklan Produk FMCG Januari-Sepetember (2017) Tumbuh Positif. Diakses 11 Oktober (2018)

Martono, M., dan S. R Iriani. (2014). “Analisis Pengaruh Kualitas Produk, Harga Dan Promosi Terhadap Minat Beli Konsumen Produk Batik Sendang Duwur Lamongan", Jurnal Ilmu Manajemen, Vol. 2, No. 2, pp. 687-692.

Mirabi, V., Akbariyeh, H., \&Tahmasebifard, H. (2015). A Study of Factors Affecting on Customers Purchase IntentionCase Study: the Agencies of Bono Brand Tile in Tehran. Journal of Multidisciplinary Engineering Science and Technology (JMEST)Vol. 2 Issue 1: 1:pep?

Naveen, G. (2016). An examination of antecedents of conversion rates of ecommerce retailers.Journal of Robert B. Pamplin Jr. School of Business Administration, University of Portland, USA, 82(114) : 82-114

Nurhaeni, Nelly. (2014). Analisis Pengaruh Kualitas Pelayanan, Word of mouth, dan Lokasi terhadap Keputusan Pembelian Jasa.

Sastika. ((2016)). Analisis Pengaruh Kualitas Website E-Commerce Traveloka Terhadap Keputusan Pembelian. Seminar Nasional. ISSN: 2089-9815

Sutisna. 2001. Perilaku Konsumen dan Komunikasi Pemasaran. Bandung : Remaja Rosdakarya.

Shimp, Terence A, J Craig Andrews. (2012). Advertising Promotion and Other Aspects of Integrated Marketing Communications.USA: South Western Educational Publishing. Si-

Umamy,C., Kumadji, S., dan Yulianto., E. (2016). Pengaruh Electronik Word Of Mouth terhadap Brand Image serta Dampaknya pada Minat Beli (Survei pada Mahasiswa Universitas Brawijaya Malang Angkatan (2015)/(2016) Penggunaan Smartphone). Jurnal Administrasi Bisnis., 33(1):114-119.

Raja, I. S., Sadfar, M., Khurshid, N., Hafeez, I. (2014). Influence of Factors in Green Advertising upon Purchase Intentions- A Study of Pakistani University Students. International Review of Management and Business Research, 3(4) : 2132-2138

Rizky, M.F., dan H Yasin. (2014). "Pengaruh Promosi Dan Harga Terhadap Minat Beli Perumahan Obama PT. Nailah Adi Kurnia Sei Mencirim Medan", Jurnal Manajemen \& Bisnis Vol. 14 No. 02, pp. 135- 143. 
Ruri Putri Utami. (2017) "Pengaruh Harga dan Kualitas Produk Terhadap Minat Beli Sayuran Organik Di Pasar Sambas Medan”, Jurnal Niagawan Vol 6 No 2 Oktober (2017).

Vejacka, Martina (2012). Facebook advertising and its efficiency on the Slovak market. Journal Economic and Management, 1: 116-126.

Wicaksono. (2016). Pengaruh Iklan dan Word of mouth Terhadap Brand Awareness Traveloka.

Winata, Wiliam. (2015). Pengaruh Iklan Pada Media Televisi Terhadap Minat Beli Es Krim Magnum Di Kota Bandung (Studi Pada Iklan Magnum Classic (2015)). Jurnal Penelitian Manajemen, Fakultas Ekonomi dan Bisnis Universitas Telkom Bandung, 6(2) : 2-6

Zamil Ahmad M Ahmad. (2011). The Impact of Word of Mouth(WOM) On the Purchasing Decision on the Jordanian Consumer . Research Jornal of International Studies 